\section{Healthy Vision Month — May 2016}

May is Healthy Vision Month, a national observance devoted to encouraging persons to make vision and eye health a priority. During this month, CDC's Vision Health Initiative in the Division of Diabetes Translation partners with the National Eye Institute's National Eye Health Education Program to educate the public about vision loss prevention and eye health promotion. May is also Older Americans Month, which offers an opportunity to raise awareness about the importance of older adults' health and well-being to their independence.

In recognition of these two observances, CDC's Vision Health Initiative recently examined the state-specific annual prevalence of falls among persons aged $\geq 65$ years with and without self-reported severe vision impairment. The study's findings, reported in this issue, indicate a higher prevalence of falls among older adults with severe vision impairment, as well as wide variation in that prevalence among states. These findings suggest that among the approximately 2.8 million persons aged $\geq 65$ years reporting severe vision impairment in 2014 (1), an estimated 1.3 million likely experienced a fall in the previous year. The findings also underscore the importance of each state implementing effective strategies to improve vision health and reduce falls, especially among older adults with severe vision impairment.

Because many common eye diseases have no immediate symptoms, early detection and timely treatment are important, as is the use of proper eye-safety practices. Developing community-based interventions for populations at high risk might reduce identified disparities in vision health. More information about vision and eye health is available from CDC (http://www.cdc.gov/visionhealth) and the National Eye Institute (https://nei.nih.gov/hvm).

\section{Reference}

1. Census Bureau. Disability characteristics. Suitland, MD: US Department of Commerce, Census Bureau; 2016. http:// factfinder.census.gov/faces/tableservices/jsf/pages/productview. xhtml?pid=ACS_12_1YR_S1810\&prodType=table

\section{Falls Among Persons Aged $\geq 65$ Years With and Without Severe Vision Impairment — United States, 2014}

\author{
John E. Crews, DPA ${ }^{1}$; Chiu-Fung Chou, DrPH${ }^{1}$; Judy A. Stevens, $\mathrm{PhD}^{2}$; \\ Jinan B. Saaddine, $\mathrm{MD}^{1}$
}

In 2014, an estimated 2.8 million persons aged $\geq 65$ years in the United States reported severe vision impairment* defined as being blind or having severe difficulty seeing, even with eyeglasses. Good vision is important for maintaining balance as well as for identifying low-contrast hazards, estimating distances, and discerning spatial relationships. Conversely, having poor vision increases the risk for falls $(1,2)$. Falls among older adults are common and can cause serious injuries, disabilities, and premature death $(1,3)$. To date, no state-level investigations have examined the annual prevalence of falls

${ }^{*}$ http://factfinder.census.gov/faces/tableservices/jsf/pages/productview. xhtml?pid=ACS_12_1YR_S1810\&prodType=table.

\section{INSIDE}

438 Global Measles and Rubella Laboratory Network Support for Elimination Goals, 2010-2015

443 Vital Signs: National and State-Specific Patterns of Attention Deficit/Hyperactivity Disorder

Treatment Among Insured Children Aged 2-5 Years — United States, 2008-2014

451 Update: Ongoing Zika Virus Transmission - Puerto Rico, November 1, 2015-April 14, 2016

456 Notes from the Field: Assessment of Health Facilities for Control of Canine Rabies - Gondar City, Amhara Region, Ethiopia, 2015

458 Announcement

459 QuickStats

Continuing Education examination available at http://www.cdc.gov/mmwr/cme/conted_info.html\#weekly.

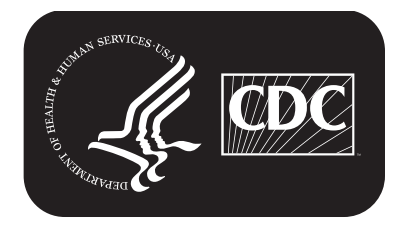

U.S. Department of Health and Human Services Centers for Disease Control and Prevention 
among persons with and without severe vision impairment. CDC analyzed data from the 2014 Behavioral Risk Factor Surveillance System (BRFSS) to estimate the state-specific annual prevalence of falls among persons aged $\geq 65$ years with and without self-reported severe vision impairment. Overall, $46.7 \%$ of persons with, and $27.7 \%$ of older adults without, self-reported severe vision impairment reported having fallen during the previous year. The state-specific annual prevalence of falls among persons aged $\geq 65$ years with severe vision impairment ranged from $30.8 \%$ (Hawaii) to $59.1 \%$ (California). In contrast, the prevalence of falls among persons aged $\geq 65$ years without severe vision impairment ranged from $20.4 \%$ (Hawaii) to $32.4 \%$ (Alaska). Developing fall-prevention interventions intended for persons with severe vision impairment will help states manage the impact of vision impairment and falls on health care resources, and can inform state-specific fall prevention initiatives.

The BRFSS is a state-based, cross-sectional, telephone surveillance system that examines health-related behavioral risk factors among the U.S. civilian population aged $\geq 18$ years. ${ }^{\dagger}$ It is administered by states and territories in collaboration with CDC. The median response rate in 2014 was $47.8 \%$; the median completion rate was $47.0 \%$.

$\overline{\dagger \text { http://www.cdc.gov/brfss. }}$
The 2014 BRFSS included questions about severe vision impairment ${ }^{\S}$ and about falls. 9 Persons who responded "don’t know" or "refused" to either question were excluded from the analyses. The study sample included 140,762 adults aged $\geq 65$ years from 50 states and the District of Columbia (DC). SUDAAN statistical software version 9.3 was used for the analyses to account for the complex sampling design. Estimates were age-adjusted and weighted to account for individual selection probabilities, nonresponse, and poststratification. State and national populations and prevalences were estimated. Statistically significant differences $(\mathrm{p}<0.05)$ were determined by a chi-square test.

Overall, $6.7 \%$ of respondents reported severe vision impairment. Among all respondents, $28.9 \%$ reported at least one fall in the previous year (Table). Among respondents who reported severe vision impairment, $46.7 \%$ reported a fall during the previous year, ranging from $30.8 \%$ in Hawaii to $59.1 \%$ in California $(\mathrm{p}<0.001)$. Among persons who did not report vision impairment, $27.7 \%$ reported a fall during the previous year, ranging from $20.4 \%$ in Hawaii to $32.4 \%$ in Alaska ( $<<0.001$ ). In 30 states, $40 \%-49 \%$ of persons with vision impairment fell,

\footnotetext{
$\$$ The BRFSS vision question is, "Are you blind or do you have serious difficulty seeing, even when wearing glasses?" Severe vision impairment was defined as a positive response to this question.

In even-numbered years, the BRFSS core survey contains the question, "In the past 12 months, how many times have you fallen?" and defines a fall as "when a person unintentionally comes to rest on the ground or another lower level." Respondents were dichotomized into either those in the last year who did or those who did not fall.
}

The MMWR series of publications is published by the Center for Surveillance, Epidemiology, and Laboratory Services, Centers for Disease Control and Prevention (CDC), U.S. Department of Health and Human Services, Atlanta, GA 30329-4027.

Suggested citation: [Author names; first three, then et al., if more than six.] [Report title]. MMWR Morb Mortal Wkly Rep 2016;65:[inclusive page numbers].

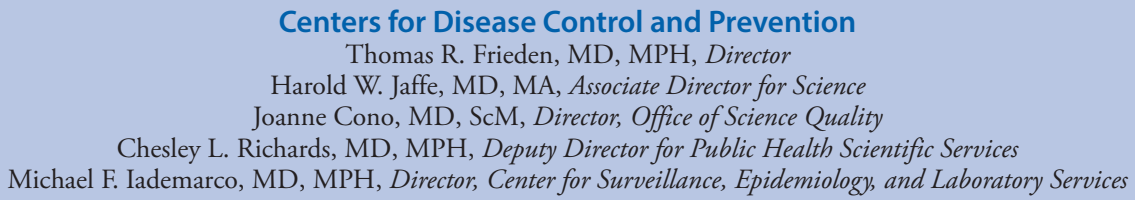

MMWR Editorial and Production Staff (Weekly)

Sonja A. Rasmussen, MD, MS, Editor-in-Chief

Charlotte K. Kent, $\mathrm{PhD}$, MPH, Executive Editor Jacqueline Gindler, MD, Editor

Teresa F. Rutledge, Managing Editor

Douglas W. Weatherwax, Lead Technical Writer-Editor

Soumya Dunworth, PhD, Teresa M. Hood, MS, Technical Writer-Editors

Timothy F. Jones, MD, Chairman

Matthew L. Boulton, MD, MPH

Virginia A. Caine, MD

Katherine Lyon Daniel, $\mathrm{PhD}$

Jonathan E. Fielding, MD, MPH, MBA

David W. Fleming, MD

Martha F. Boyd, Lead Visual Information Specialist

Maureen A. Leahy, Julia C. Martinroe,

Stephen R. Spriggs, Moua Yang, Tong Yang, Visual Information Specialists

Quang M. Doan, MBA, Phyllis H. King, Terraye M. Starr, Information Technology Specialists

MMWR Editorial Board

William E. Halperin, MD, DrPH, MPH

King K. Holmes, MD, PhD

Robin Ikeda, MD, MPH

Rima F. Khabbaz, MD

Phyllis Meadows, PhD, MSN, RN

Jewel Mullen, MD, MPH, MPA
Jeff Niederdeppe, $\mathrm{PhD}$

Patricia Quinlisk, MD, MPH

Patrick L. Remington, MD, MPH

Carlos Roig, MS, MA

William L. Roper, MD, MPH

William Schaffner, MD 
TABLE. Age-adjusted prevalence* of falls among persons aged $\geq 65$ years, by self-reported vision impairment ${ }^{\dagger}$ status and state - United States, 2014

\begin{tabular}{|c|c|c|c|c|c|c|}
\hline \multirow[b]{2}{*}{ State } & \multicolumn{2}{|c|}{ Vision impairment } & \multicolumn{2}{|c|}{ No vision impairment } & \multicolumn{2}{|c|}{ Total } \\
\hline & No.§ & $\%(95 \% \mathrm{Cl})$ & No.§ & $\%(95 \% \mathrm{Cl})$ & No.§ & $\% 95 \% \mathrm{Cl}$ \\
\hline Alabama & 24,184 & $43.4(36.4-50.7)$ & 178,857 & $28.7(26.5-31.1)$ & 203,040 & $29.8(27.7-32.1)$ \\
\hline Alaskaף & 1,781 & $45.3(30.3-61.3)$ & 20,304 & $32.4(28.0-37.1)$ & 22,085 & $33.2(29.0-37.6)$ \\
\hline Arizona & 24,352 & $39.2(32.3-46.6)$ & 226,772 & $26.8(25.2-28.4)$ & 251,124 & $27.7(26.1-29.3)$ \\
\hline Arkansas & 20,301 & $58.7(48.7-68.1)$ & 121,766 & $32.1(29.4-35.0)$ & 142,068 & $34.4(31.7-37.2)$ \\
\hline California & 169,407 & 59.1 (47.6-69.8) & 983,556 & $28.4(25.7-31.3)$ & $1,152,963$ & $30.9(28.1-33.8)$ \\
\hline Colorado & 12,119 & $37.4(28.8-46.9)$ & 148,836 & $26.6(24.8-28.4)$ & 160,955 & $27.3(25.6-29.1)$ \\
\hline Connecticut & 13,647 & $47.0(35.4-59.0)$ & 121,889 & $25.6(23.2-28.1)$ & 135,536 & $26.8(24.4-29.2)$ \\
\hline Delawareף & 2,614 & $37.3(23.3-53.8)$ & 36,776 & $28.1(25.2-31.2)$ & 39,390 & $28.4(25.6-31.4)$ \\
\hline District of Columbia & 2,829 & $51.0(36.0-65.7)$ & 18,464 & $29.3(26.0-32.8)$ & 21,293 & $31.0(27.8-34.5)$ \\
\hline Florida & 74,318 & $35.2(27.6-43.5)$ & 779,171 & $24.8(23.0-26.6)$ & 853,489 & $25.4(23.7-27.3)$ \\
\hline Georgia & 43,124 & $48.0(38.1-58.1)$ & 279,281 & $27.4(24.9-30.1)$ & 322,406 & $29.1(26.6-31.7)$ \\
\hline Hawaii & 2,530 & $30.8(19.1-45.7)$ & 40,476 & $20.4(18.0-23.1)$ & 43,005 & $20.9(18.5-23.5)$ \\
\hline Idaho? & 5,840 & $37.5(25.7-51.1)$ & 57,583 & $29.4(26.6-32.4)$ & 63,423 & $30.0(27.2-32.9)$ \\
\hline Illinois & 46,609 & $54.9(38.7-70.1)$ & 411,836 & $26.0(23.4-28.9)$ & 458,444 & $27.5(24.7-30.5)$ \\
\hline Indiana & 25,963 & $51.5(43.7-59.2)$ & 243,856 & $30.4(28.5-32.4)$ & 269,819 & $31.7(29.8-33.6)$ \\
\hline lowa & 9,297 & $46.8(35.8-58.2)$ & 132,301 & $30.8(28.7-33.0)$ & 141,598 & 31.5 (29.4-33.7) \\
\hline Kansas & 11,907 & $46.1(39.0-53.4)$ & 103,525 & $29.3(27.7-31.0)$ & 115,432 & $30.3(28.8-31.9)$ \\
\hline Kentucky & 26,934 & $46.3(35.9-57.0)$ & 164,501 & $30.9(28.4-33.5)$ & 191,435 & $32.4(29.9-35.0)$ \\
\hline Louisiana & 23,897 & $40.9(33.0-49.4)$ & 122,972 & $23.5(21.2-25.9)$ & 146,870 & $25.2(23.0-27.6)$ \\
\hline Maine & 4,069 & $51.3(40.2-62.3)$ & 63,338 & $29.6(27.6-31.7)$ & 67,407 & $30.3(28.3-32.4)$ \\
\hline Maryland & 10,515 & $35.6(26.9-45.4)$ & 180,676 & $25.1(22.9-27.3)$ & 191,191 & $25.4(23.3-27.7)$ \\
\hline Massachusetts & 30,674 & $47.7(38.3-57.3)$ & 232,550 & $27.3(25.4-29.2)$ & 263,224 & $28.6(26.8-30.6)$ \\
\hline Michigan & 48,140 & $53.4(43.2-63.3)$ & 418,074 & $31.1(29.0-33.4)$ & 466,214 & $32.5(30.4-34.7)$ \\
\hline Minnesota & 16,267 & $43.4(34.9-52.3)$ & 173,790 & $25.7(24.1-27.3)$ & 190,057 & $26.5(25.0-28.2)$ \\
\hline Mississippi & 13,609 & $42.2(31.4-53.8)$ & 95,772 & $26.3(23.4-29.4)$ & 109,381 & $27.6(24.8-30.6)$ \\
\hline Missouri & 23,583 & $44.8(34.5-55.5)$ & 253,825 & $32.0(29.4-34.7)$ & 277,408 & $32.8(30.2-35.4)$ \\
\hline Montana & 4,640 & $44.2(34.9-54.0)$ & 46,622 & $31.5(29.0-34.2)$ & 51,262 & $32.3(29.9-34.9)$ \\
\hline Nebraska & 5,936 & $42.1(34.5-50.1)$ & 65,575 & $27.3(25.9-28.8)$ & 71,510 & $28.1(26.7-29.6)$ \\
\hline Nevada & 14,246 & $44.5(31.7-58.1)$ & 85,860 & $26.1(22.6-29.9)$ & 100,106 & $27.7(24.3-31.4)$ \\
\hline New Hampshire & 4,642 & $45.8(31.6-60.7)$ & 49,598 & $27.1(24.5-29.8)$ & 54,240 & $28.0(25.5-30.7)$ \\
\hline New Jersey & 30,544 & 41.8 (32.4-51.8) & 254,566 & $22.7(20.7-24.9)$ & 285,110 & $23.9(21.9-26.0)$ \\
\hline New Mexico & 9,998 & $50.5(40.8-60.1)$ & 67,539 & $26.3(23.9-28.7)$ & 77,537 & $28.0(25.7-30.4)$ \\
\hline New York & 70,967 & $39.9(28.4-52.5)$ & 656,123 & $26.9(24.3-29.7)$ & 727,090 & $27.7(25.2-30.4)$ \\
\hline North Carolina & 42,971 & $40.2(32.2-48.8)$ & 338,647 & $27.5(25.3-29.9)$ & 381,617 & $28.5(26.4-30.8)$ \\
\hline North Dakota & 2,560 & $44.9(32.8-57.8)$ & 24,813 & $26.1(23.6-28.7)$ & 27,373 & $27.2(24.8-29.7)$ \\
\hline Ohio & 57,032 & 51.7 (41.4-61.7) & 441,646 & $28.4(26.2-30.7)$ & 498,678 & $29.8(27.7-32.1)$ \\
\hline Oklahoma & 16,450 & $44.5(36.3-53.0)$ & 142,903 & 29.7 (27.7-31.9) & 159,353 & $30.8(28.8-32.8)$ \\
\hline Oregon & 15,716 & 54.5 (42.9-65.7) & 167,689 & $30.6(28.1-33.2)$ & 183,406 & $31.8(29.4-34.4)$ \\
\hline Pennsylvania & 46,270 & $48.4(39.6-57.3)$ & 518,933 & $27.7(25.8-29.8)$ & 565,204 & $28.8(26.8-30.8)$ \\
\hline Rhode Island & 3,664 & $44.5(33.7-55.8)$ & 37,037 & $25.7(23.3-28.4)$ & 40,701 & $26.7(24.3-29.3)$ \\
\hline South Carolina & 26,792 & $47.9(40.7-55.3)$ & 181,227 & $28.2(26.3-30.2)$ & 208,020 & $29.8(27.9-31.7)$ \\
\hline South Dakota & 5,302 & $57.0(44.8-68.4)$ & 29,074 & $26.1(23.2-29.3)$ & 34,376 & $28.3(25.4-31.5)$ \\
\hline Tennessee & 37,676 & $49.1(39.4-58.9)$ & 231,815 & $29.6(26.8-32.5)$ & 269,491 & $31.1(28.4-33.9)$ \\
\hline Texas & 114,897 & $49.1(40.0-58.3)$ & 742,627 & $30.0(27.5-32.6)$ & 857,524 & $31.5(29.1-34.1)$ \\
\hline Utah & 8,954 & $52.6(43.4-61.6)$ & 72,355 & $28.4(26.5-30.4)$ & 81,308 & $29.9(28.0-31.9)$ \\
\hline Vermont $\mathbb{n}^{\Uparrow}$ & 2,008 & $43.5(30.7-57.3)$ & 28,925 & $31.6(28.9-34.3)$ & 30,933 & $32.2(29.6-34.9)$ \\
\hline Virginia & 30,020 & $42.9(33.2-53.3)$ & 248,024 & $24.7(22.6-27.1)$ & 278,044 & $25.9(23.7-28.1)$ \\
\hline Washington & 26,753 & $46.4(37.6-55.4)$ & 255,718 & 29.8 (27.8-31.9) & 282,470 & $30.9(28.9-32.9)$ \\
\hline West Virginia & 12,740 & $34.1(27.4-41.6)$ & 70,809 & $25.9(23.6-28.4)$ & 83,548 & $26.9(24.7-29.3)$ \\
\hline Wisconsin? & 8,396 & $39.4(25.6-55.2)$ & 181,745 & $27.5(24.5-30.7)$ & 190,142 & $27.7(24.8-30.9)$ \\
\hline Wyoming & 2,373 & $44.0(35.4-53.0)$ & 21,584 & $31.3(28.8-34.0)$ & 23,957 & $32.3(29.9-34.9)$ \\
\hline Total & $1,290,055$ & $46.7(44.5-49.0)$ & $10,572,200$ & $27.7(27.2-28.1)$ & $11,864,255$ & $28.9(28.4-29.4)$ \\
\hline
\end{tabular}

Abbreviation: $\mathrm{Cl}=$ confidence interval.

* Weighted estimates, age adjusted to the 2000 U.S. standard population.

† Respondents were asked, "Are you blind or do you have serious difficulty seeing, even when wearing glasses?"; "In the past 12 months, how many times have you fallen?" Respondents who refused to answer, reported "don't know," or who had other missing responses were excluded from the analyses.

$\S$ Weighted numbers.

I States without significant difference in falls between those with vision impairment and no vision impairment. 
and in 11 states and DC, approximately half of older adults with severe vision impairment fell. Extrapolating these findings to the U.S. population in 2014, an estimated 1.3 million persons $\geq 65$ years with severe vision impairment fell in the previous year.

\section{Discussion}

Approximately 2.8 million older adults have severe vision impairment, ${ }^{* *}$ a condition associated with chronic diseases, depression, and social isolation (4). During 2014, vision problems were estimated to cost $\$ 145$ billion annually (5). Vision impairment is associated with falls, which occur frequently among older adults and often cause long-term disabilities (2). In 2013, the direct medical costs of falls among persons aged $\geq 65$ years were $\$ 34$ billion (6).

In this assessment, $46.7 \%$ of adults aged $\geq 65$ years with severe vision impairment fell, compared with $27.7 \%$ of those without severe vision impairment. The differences were statistically significant in all but six U.S. states (Alaska, Delaware, Hawaii, Idaho, Vermont, and Wisconsin). In 11 states and DC, approximately half of older adults with severe vision impairment fell. In 2014, an estimated 1.3 million persons aged $\geq 65$ years with severe vision impairment fell in the previous year.

These findings are consistent with those from previous investigations that found an association between vision impairment and falls (2). Factors associated with falls include contrast sensitivity and poor balance, as well as poor visual acuity (2). Additional reasons include multiple chronic conditions, gait problems, lower extremity muscle weakness, and the use of multiple medications, some of which might exacerbate these problems ( 7 ). Addressing these risk factors would require a range of interventions, including education, medical risk management, exercise, and home modifications (7), as well as improved access to and use of eye care. Evidence-based interventions to prevent falls among older persons have been identified (http://www.cdc. gov/homeandrecreationalsafety/falls/community_preventfalls. html). In the only randomized controlled trial to date that evaluates fall-prevention interventions among older adults with vision impairment, investigators reported that, of the two interventions examined, a home safety intervention (e.g., increasing illumination, removing throw rugs, etc.), but not a strength and balance training program, significantly reduced falls among persons with vision impairment aged $\geq 75$ years in New Zealand (8).

A number of evidence-based fall interventions address environmental hazards using occupational therapists (http://

\footnotetext{
** http://factfinder.census.gov/faces/tableservices/jsf/pages/productview. xhtml?pid=ACS_12_1YR_S1810\&prodType=table.
}

\section{Summary}

What is already known about this topic?

Vision impairment is associated with falls among persons aged $\geq 65$ years. Limited state-level data exists on the prevalence of falls among older persons with vision impairment.

What is added by this report?

A state-based, cross-sectional, telephone survey of noninstitutionalized U.S. adults aged $\geq 65$ years found that $28.9 \%$ of respondents reported at least one fall in the previous year. Among the $6.7 \%$ of respondents who reported severe vision impairment, $46.7 \%$ reported a fall, ranging from $30.8 \%$ in Hawaii to $59.1 \%$ in California.

What are the implications for public health practice?

It is important to develop fall prevention interventions intended for persons with severe vision impairment and for each state to identify and implement effective strategies both to reduce falls and improve vision, especially among those with severe vision impairment.

www.cdc.gov/homeandrecreationalsafety/falls/compendium.html), but these interventions are not designed for persons with vision impairment. Given the variety of visual factors associated with falls (visual acuity, visual fields, and contrast sensitivity) as well as visual barriers in educational materials (print size, poor contrast, and visual clutter) (9), randomized controlled trials of fall-prevention interventions intended for persons with severe vision impairment are needed (10).

The findings in this report are subject to at least five limitations. First, BRFSS data are self-reported and the accuracy of responses might be affected by recall, social desirability, or other factors. Second, these data are cross-sectional and do not permit causal inference. Third, although these estimates are age-adjusted, they do not account for differences such as health behaviors or chronic conditions that might be associated with vision impairment and also contribute to falls. Fourth, the median response rate was low $(<50 \%)$. Finally, all of the excess falls among persons with severe vision impairments might not be caused by vision impairments.

Many state health departments are committed to reducing falls among older adults. The prevalence of falls among adults aged $\geq 65$ years with severe vision impairment varies widely among states. However, the consistently high prevalence of falls among older persons with severe vision impairment suggests the need for all states to implement evidence-based fall reduction interventions specifically targeted to the needs of persons with severe vision impairment as well as to improve methods to prevent vision impairment. This approach might lead to fewer injuries, higher quality of life, and greater independence among older adults, as well as reduced health care costs. 
${ }^{1}$ Vision Health Initiative, Division of Diabetes translation, National Center for Chronic Disease Prevention and Health Promotion, CDC; ${ }^{2}$ National Center for Injury Prevention and Control, CDC.

Corresponding author: John E. Crews, JCrews@cdc.gov, 770-488-1116.

\section{References}

1. Herndon JG, Helmick CG, Sattin RW, Stevens JA, DeVito C, Wingo PA. Chronic medical conditions and risk of fall injury events at home in older adults. J Am Geriatr Soc 1997;45:739-43. http://dx.doi. org/10.1111/j.1532-5415.1997.tb01480.x

2. Lord SR, Smith ST, Menant JC. Vision and falls in older people: risk factors and intervention strategies. Clin Geriatr Med 2010;26:569-81. http://dx.doi.org/10.1016/j.cger.2010.06.002

3. Morrison A, Fan T, Sen SS, Weisenfluh L. Epidemiology of falls and osteoporotic fractures: a systematic review. Clinicoecon Outcomes Res 2013;5:9-18.

4. Reed-Jones RJ, Solis GR, Lawson KA, Loya AM, Cude-Islas D, Berger CS. Vision and falls: a multidisciplinary review of the contributions of visual impairment to falls among older adults. Maturitas 2013;75:22-8. http://dx.doi.org/10.1016/j.maturitas.2013.01.019
5. Wittenborn J. The future of vision: forecasting the prevalence and cost of vision problems. In: Prevent Blindness 2014. Chicago, IL: NORC at the University of Chicago; 2014.

6. Stevens JA, Corso PS, Finkelstein EA, Miller TR. The costs of fatal and non-fatal falls among older adults. Inj Prev 2006;12:290-5. http:// dx.doi.org/10.1136/ip.2005.011015

7. Steinman BA, Nguyen AQ, Pynoos J, Leland NE. Falls-prevention interventions for persons who are blind or visually impaired. Insight: Res Pract Vision Impairment Blindness 2011;4:83-91.

8. Campbell AJ, Robertson MC, La Grow SJ, et al. Randomised controlled trial of prevention of falls in people aged $>$ or $=75$ with severe visual impairment: the VIP trial. BMJ 2005;331:817. http://dx.doi. org/10.1136/bmj.38601.447731.55

9. Williams AS. Making diabetes education accessible for people with visual impairment. Diabetes Educ 2009;35:612-21. http://dx.doi. org/10.1177/0145721709335005

10. Tricco AC, Cogo E, Holroyd-Leduc J, et al. Efficacy of falls prevention interventions: protocol for a systematic review and network meta-analysis. Syst Rev 2013;2:38. http://dx.doi.org/10.1186/2046-4053-2-38 